\title{
Confusion about site deepens further
}

THE need for a European scientific institution with supranational powers of decision has become even more apparent with the confusion over the site for the proposed European Synchrotron Radiation Source (ESRS). This $5 \cdot \mathrm{GeV}$ intense light source is almost certain to be constructed in Grenoble near the French Alps, but there is still no sign of a formal international agreement on the matter.

Even French government sources describe the situation as "confused", although there is still confidence in Paris that eventually all will go in favour of Grenoble. Meanwhile, however, the slighted French city of Strasbourg in Alsace has gone to law against the Grenoble "decision"; and the international commission set up by the European Science Foundation and charged with finding a site for ESRS is continuing visits to possible sites, most recently Trieste (proposed by Italy) and earlier Risø (Denmark).

Paris is watching these visits with a certain degree of surprise, believing the matter to have been effectively closed by the joint decision of France and West Germany to share most of the costs of ESRS at Grenoble and a cryogenic, high-Reynoldsnumber wind tunnel near Cologne and, moreover, believing that the international commission is essentially powerless, as it was given no exact terms of reference.

Three main issues are outstanding. Strasbourg's case against the French government is based on the text of contracts signed between the government and Alsace in November 1983, in which the government promised to develop Strasbourg as a "European centre" (as part of the government's overall regional strategy). The text says at first ambiguously that "the French government will support Strasbourg in its negotiations with its European partners"', but continues with a list of five examples to which, by implication, the "support" might be supposed to apply. Among them is the European Synchrotron Radiation Source. At that time, however, the Grenoble site had not been proposed, and it proved finally to be more appropriate, according to the French research minister. Fiercely determined to press its case, the Alsace regional council has put the facts before the Conseil d'Etat, France's highest court, but it is unlikely to win. Moreover, Alsace is in opposition hands and an Alsatian victory would be severely painful to an already battered administration.

After Strasbourg, there is the international commission, which might establish a consortium of small states to join the Grenoble ESRS as a body.
Finally, there is the question of cash and management of ESRS, which Paris sources describe as the real "international question". The Grenoble "site" now appears to be in three parts, and a steering committee is required to work out detailed site assessments and finalize a design. The French government believes that the steering committee could be established with only French and German members. West Germany disagrees, but seems likely soon to come under French pressure. West

Germany is keen to begin work on the wind tunnel - but France may insist that the pace of work on the tunnel be at least matched by work on ESRS. And since the West German government proposed the wind tunnel/ESRS package in the first place, it may be forced to agree and so set up a purely binational steering group for ESRS in Grenoble.

Thus it is possible that detailed design of a Grenoble ESRS could begin in just a few weeks. West Germany and France have between them offered two-thirds of the capital cost of ESRS, and while the other third must come from other partners such as the offended Italy and Denmark, or impecunious Britain, the steering committee would be expected to have up to two years of work ahead of it before that money will be required. Robert Walgate

\section{US space}

\section{Commercialization set back}

\section{Washington}

THE National Aeronautics and Space Administration (NASA), while announcing new incentives to attract commercial investment in space, is acknowledging that any profits to be had in space manufacturing will be a "long-term proposition"'. The NASA official appointed to head the agency's new office to promote commercialization, Isaac Gillam, has injected a heretofore absent note of caution in NASA's grand plans for space commerce. At a meeting organized last week in Washington by a Cambridge, Massachusetts, consulting firm that hopes to sell analysis, advice and financial services to would-be space investors, Gillam said it is "extremely important that we do not oversell the effort" at this stage, adding that he doubted there would be many successful new space business in this decade.

To overcome the most obvious barrier to space investment - the high cost of launches - NASA has taken some drastic steps, offering to shoulder many of the start-up costs for private companies willing to get into the space business. Under the new NASA policy, it will offer free rides to private companies during the research phase of their work, and may even put up several million dollars as "seed money" for selected research projects. NASA is also formulating plans for offering purchase agreements for certain space products.

NASA has already entered into "joint endeavors" with McDonnell Douglas and Johnson \& Johnson, which hope to manufacture an undisclosed hormone using electrophoresis in space; John Deere, the farm machinery company which hopes to carry out experiments on new alloys; and 3M Company, which on a series of flights over the next year will study production of organic crystals.

Initial results of experiments in space have been mixed. Although 3M's one experiment was reported to be an "un- qualified" (and unelaborated) success, the McDonnell Douglas work has been plagued with difficulties. On the recent flight of the shuttle Discovery, which carried McDonnell Douglas's own astronaut to run the electrophoresis apparatus, bacterial contamination in the equipment apparently got out of hand; bacterial endotoxins deactivated the product. The experiment is now being rescheduled for next summer. The company had hoped to fly a production-scale unit; with 24 times the capacity of the experimental one, next summer; that will have to be postponed until the end of next year at the earliest.

According to McDonnell Douglas scientists, the apparatus was sterilized two days before being loaded on the shuttle for launch, and the damaging bacterial growth apparently occurred during the week-long mission.

The $3 \mathrm{M}$ Corporation is the most enthusiastic so far. It recently submitted an elaborate plan for a series of experiments that would fly on 72 shuttle missions over the next ten years. Under the proposal, NASA would foot the bill during the research phase; in return, $3 \mathrm{M}$ would agree to make public its research findings within specified periods. Data from experiments on growing thin crystalline films would be released in two stages, 50 per cent immediately and the balance within a year; data from later experiments would be published within three years of the flight.

NASA meanwhile is preparing to show that at least something can be made quickly in space that someone might want to buy: in a few months it will begin to market the 20 micrometre latex spheres that it has been cranking out on recent shuttle flights. NASA administrator James Beggs said last week that the potential market for the spheres is $\$ 100$ million per year, a suggestion received with a certain scepticism as the only certain application is in calibration of microscopes.
Stephen Budiansky 